\title{
Buffaloberry [Shepherdia canadensis (L.) Nutt.] fruit production in fire-successional bear feeding sites
}

\author{
DAVID HAMER
}

Author is instructor, Northem Lights College, Box 1000, Fort St. John, British Columbia V1J 6KI.

\begin{abstract}
Buffaloberry [Shepherdia canadensis (L.) Nutt.] fruits are the usual late-summer food for bears (Ursus spp.) in the Front Ranges of Banff National Park, but little is known about the effect of fire or other factors on fruit production. I assessed the association between fruit production (fruits $\mathrm{m}^{-2}$ of buffaloberry shrub) and environmental factors at 76 plots in Banff National Park and found a negative association with forest canopy cover. Forest canopy cover accounted for $70 \%$ of the variation in fruit production. Fruit production also decreased from NNE- to SSWfacing slopes, but this effect was small compared to the decrease associated with increasing forest canopy cover. Forty plots were re-established at or near the original 76 sites the following year. A strong negative association between fruit production and forest canopy cover again occurred, but there was no significant association between fruit production and slope aspect. Fruit production began 5 years after fire in 2 recent burns. In sites burned 23 and 25 years ago, fruit production was comparable to that recorded in older-aged burns, and already was low at one site in the 25-year-old burn where regenerating lodgepole pine (Pinus contorta Dougl.) canopy cover measured 72\%. Many sites in older burns, however, have remained forest-free due to xeric site conditions, chinook wind, avalanching, or other factors. These open sites were associated with abundant fruit. Managers must consider the prolonged effects of fire when assessing relationships among fire, forest canopy cover, and buffaloberry fruit production.
\end{abstract}

Key Words: forest canopy, prescribed burning, range improvement, Ursus americanus, Ursus arctos, wildfire, Banff National Park.

Fruits and conifer seeds often are high-energy food for bears (Ursus spp.) during the critical late-summer and autumn fattening or "hyperphagic" period, when bears have high pre-hibernation energy requirements. Conversely, low abundance of fruits and conifer seeds can limit bear numbers. Mattson et al. (1991) concluded that the Yellowstone grizzly bear (U. arctos) population is limited primarily by the lack of fleshy fruits in its ecosystem and secondarily by the irregularity of whitebark pine (Pinus albi-

Research was supported by Parks Canada and Northem Lights College, and by Peter Achuff, Finola Finlay, Ian Pengelly, and Cliff White. Tom Gilmore and Al Schultz assisted in the field. Roger Gale and Cheri Hermans provided computer assistance. Peter Achuff, Katherine Kendall, Ian Pengelly, and anonymous reviewers made valuable suggestions on earlier versions of the manuscript.

Manuscript accepted 3 Dec. 1995. caulis Engelm.) seed production. In southwestern Washington, a 33\% decrease in the adult black bear (U. americanus) population on Long Island was attributed to declining fruit production as clearcuts underwent conifer regeneration (Lindzey et al. 1986). Low abundance of fruits and seeds also can lead to foraging activities that contribute to increased man-bear conflicts (Rogers 1976). More bears are killed in years of poor fruit or seed production (Herrero 1985:171, Mattson et al. 1992).

In the drier, eastern portions of Banff National Park, buffaloberry [Shepherdia canadensis (L.) Nutt.] fruits are the usual late-summer food for bears. In 3 of the 4 years of a grizzly bear study in the Front Ranges of Banff, buffaloberries were the major food in August and September (Hamer and Herrero 1987a). In the year of highest fruit production, buffaloberries remained the grizzly bear's major food until denning occurred in November. Comparable results were obtained in a study of black bears in Banff (Raine and Kansas 1990), and in other Front-Ranges studies (Russell et al. 1979, Wielgus 1986, Holcroft and Herrero 1991).

Buffaloberry characteristically is a fire-successional species. Fisher and Clayton (cited in Noste and Bushey 1987) classified it as moderately resistant to fire because buffaloberry could be destroyed by fire in some cases (cf. Stickney 1980). McLean (1969), however, considered buffaloberry resistant even to severe fire. Buffaloberry resprouts following fire from surviving root crowns and dormant buds located on the taproot (Noste and Bushey 1987); it also resprouts from buds on lateral roots (pers. obs.). Fire maintains extensive lodgepole pine (Pinus contorta Dougl.) forests in Alberta, which on drier sites are dominated in the shrub layer by buffaloberry (La Roi and Hnatiuk 1980). In Banff, Hamer and Herrero (1987b) recorded grizzly bears feeding on buffaloberry in fire-successional shrubland and regenerating forests originating from 1936, 1929, 1914, and 1889 wildfires (41 to 90 years since fire). In contrast to use of these fire successional habitats, Hamer and Herrero (1987b) did not record bears feeding on buffaloberry in climax stands even though mature spruce forests $>300$ years old covered $29 \%$ of their core study area.

Specific information on buffaloberry fire ecology is lacking. In their assessment of the fire-response information available for 21 shrub species, Noste and Bushey (1987) gave buffaloberry and falsebox [Pachistima myrsinites (Pursh) Raf.] the lowest possible rating regarding available information. Noble (unpublished ms. on file at USDA Forest Serv. Intermountain Res. Sta., Missoula, Mont.) measured buffaloberry fruit production in southeast British Columbia. Highest production was recorded in 2 sites 
within a 1928 burn. Noble concluded, however, that because of his small sample size (8 transects), a "serious lack of data prohibits an in depth analysis."

Earlier observations of grizzly bear feeding ecology in Banff National Park suggested that buffaloberry fruit production decreased with increasing forest canopy (Hamer and Herrero 1987a). Bear feeding areas thus were often associated with firesuccessional forest openings and less commonly with avalanche paths (Hamer and Herrero 1987b). Slope aspect and elevation were not obviously related to fruit production, but steep slopes sometimes were related, for example, by leading to avalanching or slow forest regeneration following fire.

The objectives of this study were to assess the associations between fruit production and environmental variables (forest canopy cover, slope aspect, steepness, elevation, plant-community type, time since stand-replacing fire), and to relate the results to management of bear habitat. A secondary objective was to document the lag between fire and resumption of fruit production in recent burns.

\section{Study Area}

The study area included 4 locations in Banff National Park and 1 location in the Ghost River Wilderness Area, Alberta, $3 \mathrm{~km}$ east of the Banff park boundary. All locations were on the eastern slopes of the Rocky Mountains in the rain shadow of more westerly ranges. The rain shadow effect is exacerbated by the warm chinook (foehn) SW winds that characterize the east slopes. These very strong, gusty, desiccating winds occur when Pacific air descends the eastern slopes of the Rocky Mountains (Janz and Storr 1977).

The primary study area (67\% of 1993 study plots) was located in the subalpine zone of the Cascade Valley, $45 \mathrm{~km}$ east of the continental divide. The Cascade plots were located in the upper portion of the valley (upstream of Stony Creek) where fires of $1889,1914,1929$, and 1936 created extensive seral communities (Hamer and Herrero 1987b). In addition, approximately $5 \mathrm{~km}^{2}$ of the 1914 burn were prescription-burned by Parks Canada in 1986 (a low-severity spring burn) and 1990 (a moderate-severity autumn burn). The secondary study area (21\% of 1993 study plots) was located in the subalpine zone of the Spray Valley, 40 $\mathrm{km}$ SSE of the Cascade study area, where the 2 most recent fires burned in 1908 and 1928 (M.P. Rogeau, Parks Canada, unpublished data). Annual precipitation in these 2 Front Range study areas is 750 to $1,000 \mathrm{~mm}$ ( 500 to $750 \mathrm{~mm}$ for lower-valley portions) according to extrapolations made by Janz and Storr (1977).

Two additional Front Range study areas were selected because of their more recent fires: the Lake Minnewanka 1988 prescription burn, located $20 \mathrm{~km} \mathrm{SE}$ of the Cascade Valley study area in the lower-elevation montane zone (5\% of 1993 study plots); and the 1970 Ghost River burn, located in the subalpine zone $20 \mathrm{~km}$ ESE of the Cascade Valley study area (3\% of 1993 study plots). Annual precipitation was extrapolated to be 380 to $500 \mathrm{~mm}$ in the Minnewanka study area (Janz and Storr 1977), and likely is 500 to $750 \mathrm{~mm}$ in the Ghost River area, judging from extrapolations for adjacent portions of Banff National Park.

The fifth study area, also chosen because of its recent fire, was on Altrude Creek in the 1968 Vermilion burn, $25 \mathrm{~km} \mathrm{SSW}$ of the Cascade Valley study area (4\% of 1993 study plots). Although in the Main Ranges, annual precipitation in the Altrude watershed was extrapolated to be 500 to $750 \mathrm{~mm}$ (Janz and Storr 1977).

Vegetation in the Cascade and Spray study areas was predominantly seral forest dominated by lodgepole pine, and mature forest dominated by spruce [Picea engelmannii Parry ex Engelm. $\mathrm{x}$ $P$. glauca (Moench) Voss]. Although coniferous forest was abundant, many slopes below the altitudinal treeline were completely or partially forest-free, in part because of recent fire, low precipitation, and strong chinook winds. Avalanches had a relatively minor role because of low precipitation. In the Cascade study area, coniferous forest covered about $67 \%$ of the area and subalpine grassland and shrubland covered about 33\% (Hamer 1985:108). In the 3 study areas burned in 1988, 1970, and 1968, vegetation was mostly grassland (1988 burn) or shrubland (1970 and 1968 burns) although lodgepole pine was regenerating on some sites in the 2 older burns.

\section{Methods}

\section{Plot Location-1993 and 1994}

Field data were collected during July 6 to 27,1993 (76 plots) and July 5 to 13, 1994 (40 plots). In 1993, 51 plots were established in the Cascade Valley and 25 in the 4 secondary study areas. In 1994, 35 plots were re-established in the Cascade and 5 in the Vermilion burn. Plot centers were located by walking a fixed number of paces into a site. Usually 70 paces $(50 \mathrm{~m})$ were used, although for small gulley-sides, 24 paces $(20 \mathrm{~m}$ ) sometimes were used. In large, homogeneous sites, more than 70 paces were used. Thus "edges" were not sampled except when edge was inherent to the site (e.g., in spatially-restricted "microhabitat" such as gulley-sides). Plots were placed $>100 \mathrm{~m}$ apart.

Sites were chosen subjectively to include a wide range of habitat where buffaloberry had $\geq$ about $5 \%$ cover. In the primary study area (Cascade Valley) roughly two-thirds of the sites were known from direct sightings or inferred from radio-tracking and site examination to have been intensively used by grizzly bears feeding on buffaloberries during 1977 to 1979 (Hamer and Herrero 1987a, b). Other sites in the Cascade Valley and all sites in the secondary study areas were of unknown status as bear feeding habitat. These sites were selected to include the numerous combinations of buffaloberry-containing vegetation types, elevation, forest canopy cover, slope aspect, and slope steepness that characterize the complex mountain topography of the study areas; and sites also were selected to include specific "microhabitat" important as bear feeding habitat, such as gulley-sides and narrow ( $<100-\mathrm{m}$ wide) shrubland ecotones between forest and grassland. Subjective site selection with systematic location of plot centers thus was used to facilitate sampling of this diverse array of buffaloberry habitat. When sites were not in known feeding areas, potential sites were located from map and valley overviews. Sites never were chosen based on subjective appraisal of fruit production. It was not possible to establish plots in all potential habitat categories because of limited time and because certain categories such as north-facing slopes or mature forest often lacked buffaloberry cover.

Because knowledge of grizzly bear feeding sites was used to locate many Cascade plots, the 51 plots occurred over a relatively large portion of the valley (about $50 \mathrm{~km}^{2}$ ). Comparable data on grizzly bear feeding sites were unavailable for the Spray Valley; 
the 16 Spray plots were located within an area sufficiently large to represent various habitat categories (about $4 \mathrm{~km}^{2}$ ). Plots for the 3 smaller study areas each were located in $<0.2 \mathrm{~km}^{2}$.

In July 1994, plots were re-established at or near some of the 1993 locations. In the Cascade Valley, more accessible locations were used. The 1993 plots were not permanently marked, but in 16 sites with distinctive features it was possible to re-establish plots within a few meters of 1993 locations. In the remaining sites, plots were located within a few hundred meters of 1993 locations.

\section{Plot Location-1995}

To assess whether comparable results would be found using a random sampling design, 18 plots were established during 6 to 17 July 1995 using systematic stratified random sampling in a 14 $\mathrm{km}^{2}$ portion of the Cascade Valley. Two strata were identified: extensive, open- to closed-forest typical of the study area, and spatially-restricted buffaloberry shrubland. Fourteen plots were located in the first stratum by using randomly selected map coordinates to identify one 1-ha site in each of the fourteen $1-\mathrm{km}^{2}$ blocks. The center of each site was located in the field using a 1:50,000 topographic map and altimeter, and the plot center was established by proceeding an additional $30 \mathrm{~m}$ along a randomly selected bearing. Locations having $<4 \%$ buffaloberry cover were rejected and the plot was relocated using a new set of random map coordinates. Four plots were located in the shrubland stratum by delineating 4 shrubland blocks (distance between blocks, 1 to $6 \mathrm{~km}$; block size, 10 to $70 \mathrm{ha}$ ) and randomly selecting one 1ha site in each block. Plot centers for these 4 sites were established as above.

\section{Fruit Production}

Buffaloberry fruit production [defined in this study as fruit density (fruits $\mathrm{m}^{-2}$ ) on buffaloberry shrub] was estimated by modifying the methods described by Kendall (1986: Method B). The buffaloberry fruits in forty $0.04 \mathrm{~m}^{2}(20 \times 20 \mathrm{~cm})$ quadrats were counted at each plot by running 4 transects along the fall line and placing 10 quadrats along each transect. Transects began 10 paces $(7 \mathrm{~m})$ on contour to each side of the plot center, and ran up and down the fall line from each of these 2 starting points (Fig. 1). Quadrats were located at 2-pace intervals along a transect. If a quadrat failed to contain any living part of a buffaloberry plant, it was moved to the closest part of the closest buffaloberry plant in a $180^{\circ}$ selection zone (i.e., moving along, or at right angles to, the transect) (Cole 1963; Fig. 1). In either case, the quadrat was then repositioned such that buffaloberry shrub covered the entire quadrat. The next quadrat was located by returning at right angles to the original transect and proceeding another 2 paces along the transect. By ensuring that buffaloberry shrub covered the entire quadrat, it was possible to convert to fruit production of buffaloberry shrub.

In each quadrat, all buffaloberry fruits were counted that occurred in the imaginary volume projected vertically downward from the quadrat frame held above the shrub layer. Counted fruits were removed from the shrubs to ensure each fruit was counted only once. Most plots ( $>80 \%$ ) were analyzed when fruits were green (early to mid July). In the remaining cases, fruits were just becoming ripe (late July). There thus was little likelihood that fruits had fallen or been eaten by animals. Fruits were more easily picked and counted when green.

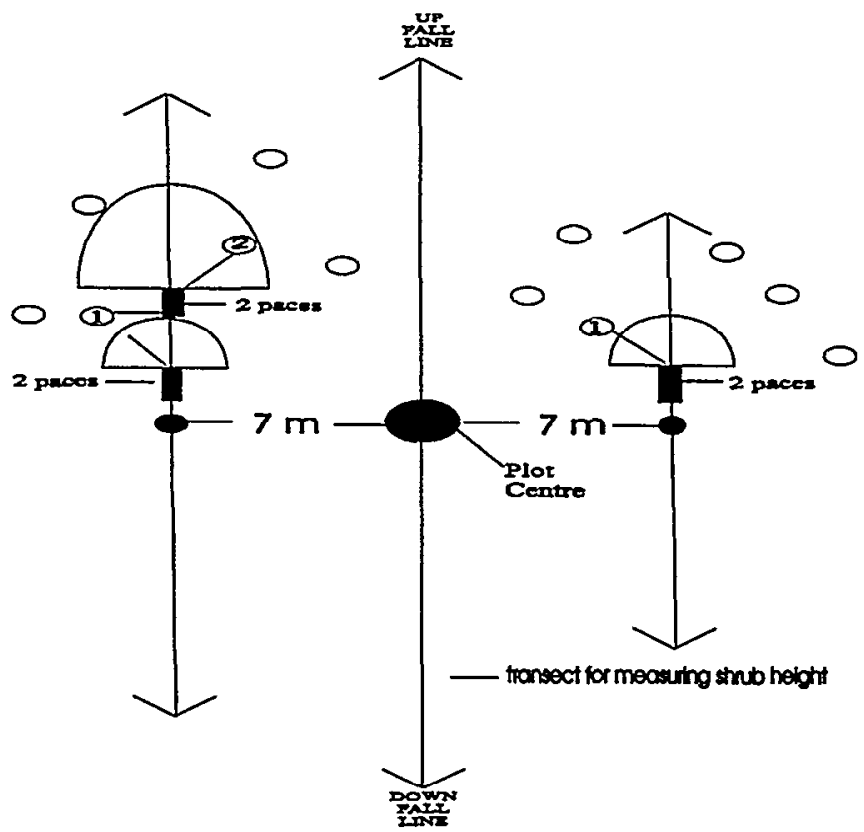

Fig. 1. Plot layout and closest-plant selection technique using a $180^{\circ}$ selection zone (Cole 1963). Illustrated (for fruit production measurement) are the first 2 of 10 selections on the left, upslope-running transect, and the first 1 of 10 selections on the right, upsloperunning transect. Small, open ellipses represent buffaloberry plants. The 2 small, closed ellipses represent the starting points for the 4 fruit-production transects.

\section{Plot Analysis}

At each plot center, slope steepness and aspect were determined by averaging upslope and downslope measurements using a compass/clinometer. Map coordinates and elevation were obtained from 1:50,000 topographic maps using, when necessary, triangulation from known landmarks and trigonometry from a point of known elevation. Slope profile and position were recorded. Fire history was determined using 1:50,000 stand origin maps being prepared for Banff National Park (M.P. Rogeau, Parks Canada, unpublished data). The vegetation type was assigned using the key and descriptions prepared by Achuff (1982) and Corns and Achuff (1982a). Soil moisture availability was estimated for each plot using Parker's (1982) Topographic Relative Moisture Index (TRMI). Because of the dominant influence of chinook wind in the study area, I modified Parker's index by weighting topographic position 0 to 10 and slope steepness 0 to 20.

Buffaloberry shrub height was used to index shrub regeneration following firc. Height was measured as the mean of the maximum heights of 10 shrubs measured along transects running along the fall line ( 5 shrubs up, 5 down). Plants were selected using the $180^{\circ}$ selection zone described above. The spacing for plant selection was 2 paces; however, the nearest plant was rejected if 2 paces resulted in selection of the same plant. Height was measured vertically between horizontal projections from the plant's rootstock and the tip of the tallest branch.

Forest canopy cover was estimated using a convex spherical crown densiometer (i.e., a convex canopy mirror divided into 24 cells; Lemmon 1956). In each plot, 8 readings were averaged by 
Table 1. Association between fruit production and environmental variables as measured by the Kendall rank-order correleation coefficient (tau) for 71 plots in Banff National Park, Alberta, where time since fire $\geq 23$ years (1993 data).

\begin{tabular}{|c|c|c|c|c|c|}
\hline & \multicolumn{5}{|c|}{ Environmental variables } \\
\hline & Forest canopy cover & Slope aspect scalar & Slope steepness & Elevation & $\begin{array}{l}\text { Soil Moisture } \\
\text { (TRMI) }^{\mathrm{a}}\end{array}$ \\
\hline & 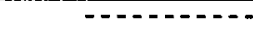 & ------ & $--(\operatorname{tau})---$ & 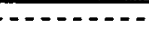 & 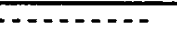 \\
\hline Slope steepness & & 0.074 & & & \\
\hline
\end{tabular}

${ }^{*} \mathrm{P}<0.05 ; * * \mathrm{P}<0.01 ; * * \mathrm{P}<0.001$ (2-trailed)

a Topographic relative moisture index

taking 4 measurements in each of 2 subplots located 15 paces (10 $\mathrm{m})$ up and 15 paces down the fall line from the plot center. The 4 readings at each subplot were taken 5 paces $(4 \mathrm{~m})$ from the subplot center along the 4 right-angle directions oriented to the fall line, with the observer facing outward from the subplot center.

\section{Shrub Regeneration Following Fire}

Some additional observations and measurements of shrub regeneration 1 to 5 years following fire were made in the 1986 and 1990 Palliser burns during 1987 to 1992 (Hamer, unpublished reports submitted to Parks Canada, Banff National Park). Methods were comparable to those described above, except that 5 macroplots, spaced either 40 or $50 \mathrm{~m}$ apart, were used for each site.

\section{Data Analysis}

Analyses were conducted on the larger data set collected during the first year of the study (1993), unless otherwise noted. Further, 5 of these plots in recent burns (1988, 1990; time since fire 5 and 3 years) were deleted from all analyses except those regarding time since fire. The buffaloberry shrubs in these 5 plots were immature; their inclusion would have confounded the effects of site condition on fruit production.

Slope aspect was converted from an angular variable to a scalar variable which reflected different temperature regimes (Reid et al. 1991, Parker 1982) by assigning the lowest value, 0, to SSWfacing aspect $\left(202^{\circ}\right)$, the maximum value, 180 , to NNE-facing aspect $\left(22^{\circ}\right)$, and by scaling other sites from 0 to 180 according to the number of degrees they differed from $202^{\circ}$. Kendall rankorder correlation coefficients were used to assess the association between fruit production and environmental variables, obviating the assumption of sampling from bivariate normal distributions. Kendall partial rank-order correlation coefficients allowed for reassessment of the strengths of correlations while holding constant the effect of a third, intervening variable. A functional relationship between fruit production and forest canopy cover was developed using regression analysis. Fruit production data (fruits $\mathrm{m}^{-2}$ ) were log-transformed for regression analysis to improve the linear relationship with forest canopy cover. Because fruit production decreased more rapidly under higher forest cover, the relationship was more closely approximated using piecewise linear regression (conducted using a mesh length of 5\%) (Nakamura 1986). The $r^{2}$ values from piecewise regression analysis were adjusted by subtracting $\mathrm{P}\left(1-\mathrm{r}^{2}\right) /(\mathrm{N}-\mathrm{P}-1)$, where $\mathrm{P}=$ the number of independent variables and $N=$ the number of cases (Dixon
1992:394). The relationship between fruit production and forest canopy cover also was reasonably approximated using simple linear regression $\left(r^{2}=67 \%\right.$ compared to $r^{2}=70 \%$ for piecewise linear regression), so simple linear regression was used to compare the Cascade and Spray study areas. The residuals from the regression of log of fruit production on densiometer readings were normally distributed (Shapiro-Wilk W=0.985, P=0.84; null hypothesis of normal distribution not rejected). All analyses were done using BMDP statistical software (Dixon 1992).

\section{Results}

\section{Site Characteristics and Fruit Production}

Significant associations between buffaloberry fruit production and 4 environmental variables were identified (Table 1). Fruit production decreased with increasing forest canopy cover (tau=0.608 ), and this negative relationship remained strong when either slope aspect, slope steepness, or elevation was held contstant (partial tau values -0.567 to $-0.615, \mathrm{P}<0.001$ ) (Table 2). A functional relationship between fruit production and forest canopy cover for 71 plots was approximated using piecewise linear regression: $70 \%$ of the variation in fruit production was accounted for by forest cover $\left(r^{2}=0.698\right)$ (Fig. 2). Above a threshold of $45 \%$ forest cover, fruit production decreased relatively rapidly with increasing forest cover.

Fruit production also increased from SSW to NNE facing slopes (tau=0.182) (Table 1; Fig. 3), and the relationship remained strong when forest canopy cover was held constant (partial tau=0.216, $\mathrm{P}<0.01$ ) (Table 2). High fruit production

Table 2. Kendall partial rank-order correlation coefficients (tau) for the association of paried variables with the effect of a third intervening variable held constant for 71 plots in Banff National Park, Alberta, where time since fire $\geq 23$ years (1993 data).

\begin{tabular}{lcll}
\hline \hline Pairs of variables & $\begin{array}{c}\text { Original } \\
\text { tau }\end{array}$ & $\begin{array}{c}\text { Variable held } \\
\text { constant }\end{array}$ & $\begin{array}{c}\text { Paritial } \\
\text { tau }\end{array}$ \\
\hline $\begin{array}{l}\text { Forest Production and } \\
\text { Forest canopy cover }\end{array}$ & $-0.608^{* * *}$ & Aspect & $-0.615^{* * *}$ \\
Forest canopy cover & $-0.608^{* * *}$ & Steepness & $-0.567^{* * *}$ \\
Forest canopy cover & $-0.608^{* * *}$ & Elevation & $-0.594^{* * *}$ \\
Slope aspect scalar & $0.182^{*}$ & Forest cover & $0.216^{* *}$ \\
Slope steepness & $0.306^{* * *}$ & Forest cover & 0.158 \\
Elevation & $0.223^{* *}$ & Forest cover & 0.158 \\
\hline
\end{tabular}

${ }^{*} \mathrm{P}<0.05 ; * * \mathrm{P}<0.01 ; * * * \mathrm{P}<0.001$ (2-tailed) 


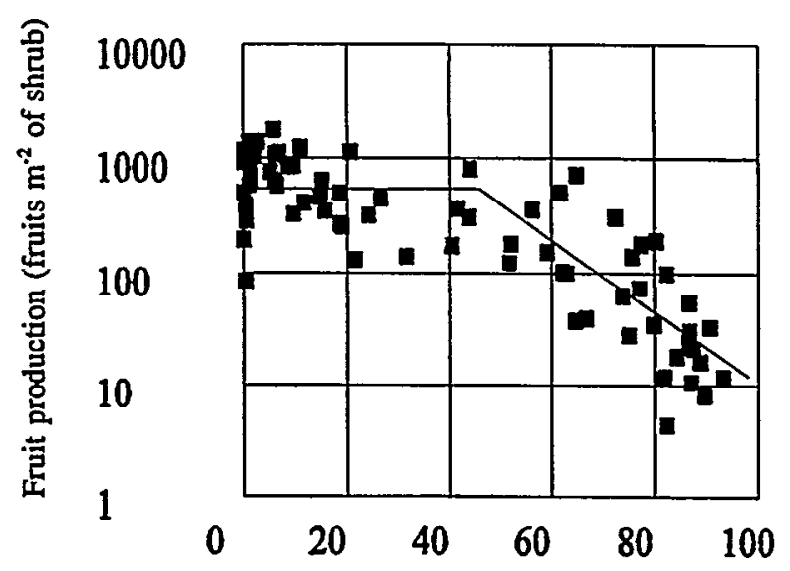

Forest canopy cover (\%)

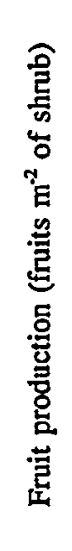

1

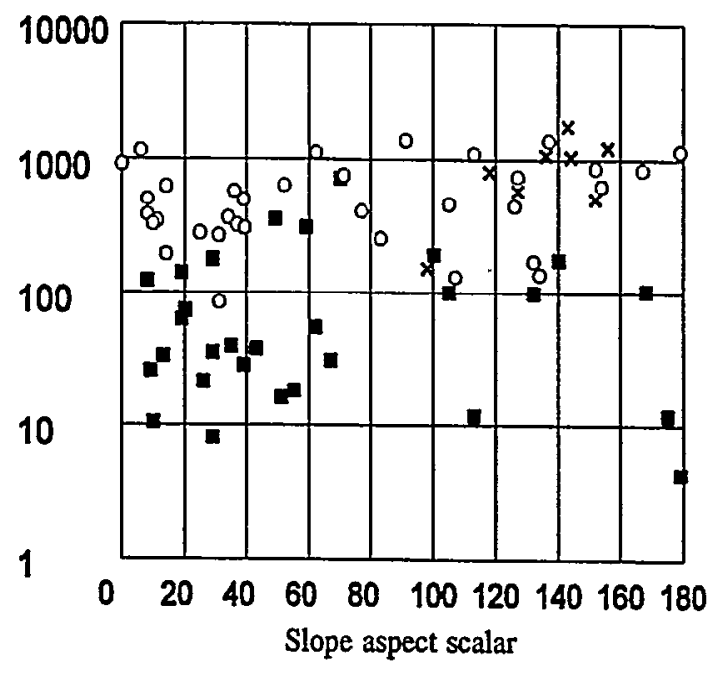

Fig. 3. Buffaloberry fruit production plotted against a slope aspect scalar $\left(0=\mathrm{SSW}\left[2^{\circ 02^{\circ}}\right] ; 180=\mathrm{NNE}\left[2^{\circ}\right]\right)$, Banff National Park, Alberta. Fruit production is graphed on a logarithmic scale. $0=$ low forest canopy cover (densiometer reading $\langle 50 \%$ ). $\square=$ high forest canopy cover (densiometer reading $\geq 50 \%$ ). $x$-plots in C37 vegetation type. $N=71$ plots where time since fire $\geq 23$ years (1993 data).

this study) may have limited value as a predictor variable.

Fruit production increased with increasing slope steepness (tau $=0.306$ ) and increasing elevation ( $\operatorname{tau}=0.223$ ), but these associations were not significant when the intervening effect of forest canopy cover was controlled (partial taus $=0.158, P>0.05$ ) (Table 2). That is, reduced forest cover was associated with steeper slopes and higher elevation, and higher fruit production in turn was associated with open site conditions. Forest canopy likely decreased as slopes became steeper $($ tau $=-0.307)$ (Table 1) because site conditions tend to be more xeric and soils thinner with increasing steepness. These less favorable conditions can inhibit forest regeneration following fire and thus maintain more open communities (Corns and Achuff 1982a, b). On some steep slopes, recurring avalances maintain open vegetation. In this study, 4 plots were on avalanche paths and 2 others probably were subject to avalanching. For comparable reasons, a denser forest canopy in lower elevation plots (tau $=-0.162$ ) (Table 1) may in part be explained because lower-elevation buffaloberry habitat in the valley bottoms of my study area typically is forested

Tuble 3. One-way nonparametric analysis of variance for the relationship between habitat categories and buffaloberry fruit production in Banff National Park, Alberta, where time since fire $\geq 23$ years (1993 data). Vegetation types with non-specific moisture regimes [S10 (2 plots), S12 (2 plots) and "other" (4 plots)] were deleted from the analysis. Kruskal-Wallis test statistic $=20.7, P<0.001$.

\begin{tabular}{|c|c|c|c|c|c|}
\hline Category & $\begin{array}{c}\text { Moisture/temperature } \\
\text { regime }\end{array}$ & $\begin{array}{l}\text { Vegetation } \\
\text { types }\end{array}$ & $\begin{array}{l}\text { Number } \\
\text { of plots }\end{array}$ & $\begin{array}{l}\text { Forest } \\
\text { cover }^{d}\end{array}$ & Fruit production ${ }^{d}$ \\
\hline $\begin{array}{l}1 \\
2 \\
3\end{array}$ & $\begin{array}{l}\text { xeric }^{\mathrm{a}} \\
\text { mesic }^{\mathrm{b}} \\
\text { mesic/cool }^{\mathrm{e}}\end{array}$ & $\begin{array}{l}\mathrm{L} 01, \mathrm{C} 03,017 / 018 \\
\mathrm{Cl}, \mathrm{C} 19 \\
\mathrm{C} 37\end{array}$ & $\begin{array}{c}29 \\
26 \\
8\end{array}$ & $\begin{array}{c}(\%) \\
17 \pm 22 \\
68 \pm 26 \\
24 \pm 26\end{array}$ & $\begin{array}{c}\text { (fruits } \mathrm{m}^{-2} \text { of shrub) } \\
500 \pm 350 \# \mathrm{H} \\
220 \pm 340 \S \\
900 \pm 500 \#\end{array}$ \\
\hline
\end{tabular}

${ }^{\mathrm{a}}$ Bearberry low shrubland (L01), pine/bearberry open forests (C03-open variant), spruce and pine/bearberry forests (C03 and O17), and spruce/willow (Salix glauca L.)/hairy wild rye (Elymus innovatus Beal) open forest (O18).

"Pine/buffaloberry/twin flower (Linnaea borealis L.) forest of SW aspect (C19) or pine/buffaloberry/grouseberry (Vaccinium scoparium Leiberg) forest of various aspects (C18).

Immature, regenerating spruce open forest with northerly aspect expected to succeed to C37 spruce/buffaloberry/feathermoss [Hylocomium splendens (Hedw.) B.S.G.] forest, thus bypassing a seral lodgepole pine forest.

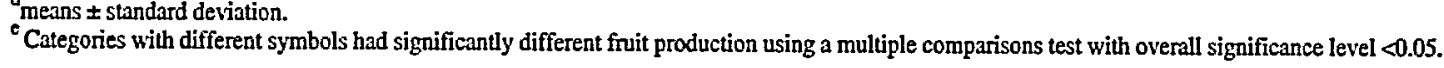


whereas higher-elevation buffaloberry habitat on the valley sides may be either forested or open depending on other factors such as slope steepness.

\section{Cascade Versus Spray Study Areas}

The Cascade Valley plots had significantly greater fruit production than plots from the Spray Valley when forest canopy cover was controlled. The slopes of the regression lines of log of fruit production versus forest canopy cover for the Cascade plots $(n=50)$ and Spray plots $(n=16)$ were not different $(t=0.61$, $\mathrm{P}>0.50$ ), suggesting that fruit production decreased comparably with increasing forest canopy cover in both study areas, but the Cascade regression line was higher on the graph $(\mathrm{t}=2.86,2$-tailed, $\mathrm{P}<0.01$; Zar 1984:292).

\section{Vegetation Types}

Fruits were abundant in a wide range of vegetation types, from xeric bearberry (Arctostaphylos uva-ursi L.) low-shrub types through mesic north-facing willow (Salix spp. L.)-dominated slopes succeeding directly to spruce forest. Xeric shrubland and open forests had higher fruit production than mesic forest types $\mathrm{C} 18$ and $\mathrm{C} 19$ but this was attributable to greater forest regeneration in the latter (Table 3). Xeric site conditions can inhibit forest regeneration in some sites, whereas mesic sites, if not subject to cool temperatures nor a seed-removing "double burn," often will regenerate rapidly to lodgepole pine forest. On the other hand, abundant fruits also occurred in the mesic/cool $\mathrm{C} 37$ vegetation type where cool site conditions on slopes facing WNW $\left(300^{\circ}\right)$ through ENE $\left(75^{\circ}\right)$ [mean NNE (14')] may have contributed to slow forest regeneration following fire (Table 3). Seven of the 8 plots in C37 vegetation were in open shrubland in a 1936 burn where spruce was regenerating slowly without prior development of a seral lodgepole pine forest. Thus, both xeric and mesic/cool sites had higher fruit abundance than mesic C18 or C19 types, which I attribute to the inhibiting influence of either xeric or cool site conditions on forest regeneration following fire.

\section{Corroboration-1994 and 1995}

Results from the second field season (1994) were comparable to those from the first year. The negative association between fruit production and forest canopy cover again remained strong when either slope aspect, slope steepness, or elevation was held constant (partial tau values 0.399 to $0.493, \mathrm{P}<0.001, \mathrm{n}=40$ ) (Table 4). Piecewise linear regression of fruit production on forest canopy cover also gave results comparable to 1993, with forest canopy cover accounting for $59 \%$ of the variation in fruit production for the 1994 plots $[Y=2.72-0.052(X-70)(Z)$; compare equation in Fig. 2]. Surprisingly, the $y$-intercept (identifying average fruit abundance in sites of low or absent forest canopy) was equal in both years, 520 fruits $\mathrm{m}^{-2}\left(2.72 \log _{10}\right.$ units). Evidently buffaloberry fruit production in the sites of low or absent forest canopy measured during this study was similar between 1993 and 1994. Fruit production remained at high levels under a denser forest canopy in 1994. The piecewise linear equation for 1994 did not slope downward until a break point of $70 \%$ forest canopy cover was exceeded, whereas a break point of $45 \%$ forest cover was identified using the 1993 data.

The association between fruit production and slope aspect (with forest cover held constant) was not significant in 1994 (partial tau $=0.150, \mathrm{P}>0.05$ ) (Table 4).
Table 4. Association between 1994 fruit production and environmental variables as measured by Kendall rank-order correlation coefricient (tau) for 39 plots in Banff National Park, Alberta, where time since fire $\geq 26$ years (1994 data).

\begin{tabular}{llll}
\hline \hline Pair of variables & Original tau & Variable held constant & Partial tau \\
\hline Fruit production and & & & \\
Forest canopy cover & $-0.480^{* * *}$ & Aspect & $-0.470^{* * *}$ \\
Forest canopy cover & $-0.480^{* * *}$ & Steepness & $-0.399^{* * *}$ \\
Forest canopy cover & $-0.480^{* * *}$ & Elevation & $-0.493^{* * *}$ \\
Slope aspect scalar & 0.161 & Forest cover & 0.150 \\
Slope steepness & $0.328^{* *}$ & Forest cover & 0.157 \\
Elevation & 0.060 & Forest cover & -0.140 \\
\hline
\end{tabular}

${ }^{*} \mathrm{P}<0.05,{ }^{* *} \mathrm{P}<0.01 ;{ }^{* * *} \mathrm{p}<0.001$ (2-tailed)

Results from the third field season, obtained using random sampling, were comparable to results from 1993 and 1994. Although small sample size in 1995 necessitates cautious interpretation, the negative association between fruit production and forest canopy cover again held (Kendall's tau $=-0.412, P<0.05$, $\mathrm{n}=18$ ). Piecewise linear regression also gave results comparable to 1993 and 1994, with forest canopy cover accounting for $55 \%$ of the variation in fruit production in 1995 [Y=2.9-0.011(X40)(Z); compare Fig. 2]. The effect of forest cover appeared less in 1995 (slope of the piecewise equation=-0.011 in 1995, compared to -0.031 in 1993 and -0.052 in 1994). This reflects higher fruit production values under the forest canopy in 1995: a mean of 220 fruits $\mathrm{m}^{-2}$ (range 116 to $308, \mathrm{n}=5$ plots) was recorded where forest canopy cover was $>70 \%$ (compare Fig. 2 where 21 plots with forest canopy $>70 \%$ averaged 65 fruits $\mathrm{m}^{-2}$ in 1993). This difference likely is due in part to small sample size in 1995, and also may reflect variation in fruit production between years.

\section{Buffaloberry Regeneration Following Fire \\ I to 5 Years After Fire}

Shrub regeneration following 3 recent prescribed fires is documented in Table 5. The 1-year lag in shoot regeneration following the 1990 Palliser fire was not due to the double burn: the same 2year interval before resprouting was observed for shrubs first burned in 1990. The autumn Palliser fire burned with greater severity than the spring Palliser fire (Drought Code for the spring fire=138; for the autumn fire $=434$; Ian Pengelly, Parks Canada, personal communication).

The 5-year interval before fruit production in the Palliser and Minnewanka burns agrees with general observations that buffaloberry (when grown from seed) first produces fruit at 4 to 6 years of age (Young and Young 1992). Five-year-old shrubs in the Minnewanka burn were much larger and more productive than those in the Palliser burn, but despite their faster recovery no fruits were observed in the Minnewanka burn 4 years after fire (Table 5).

\section{3 and 25 Years After Fire}

Fruit production in the Ghost and Vermilion burns (Table 6) was comparable to that recorded in older-aged burns (Fig. 4). Plants in the Ghost River plots were small (Table 6) presumably because of the very dry, SW-facing, colluvial site conditions. Reestablishment of shrubs 25 years postfire concurs with Mueggler's (1965) observations from seral shrub communities in Idaho where intermediate-sized shrubs (0.9 to $2.1 \mathrm{~m}$ high) reached maximum heights in about 20 years following fire. 
Table 5. Regeneration of buffaloberry shrubs 1 to 5 years following prescribed fire in Banff National Park, Alberta. Table refers only to shrubs that were killed to ground level by the fire except as noted. Unburned or partially burned shrubs within a burn unit would have had heights typical of mature shrubs and could have produced fruit in any year. Data were collected during July except as noted. Values for $>1$ plot are mean \pm 1 standard deviation.

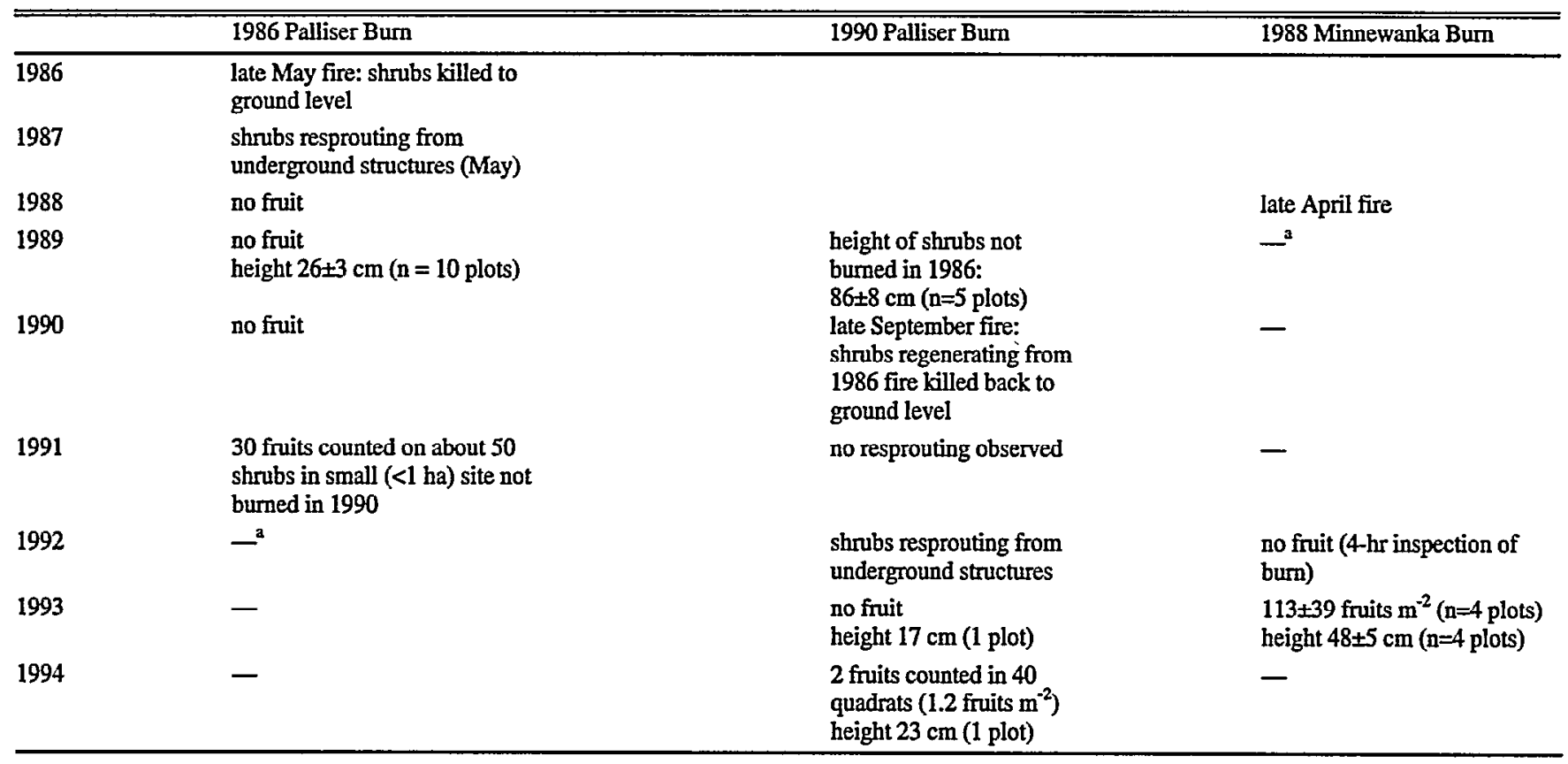

No data

The lowest-production Vermilion plot was within a regenerating lodgepole pine forest ( 310 fruits $\mathrm{m}^{-2}$; canopy cover of $72 \%$ ). In the remaining 2 plots, where few trees had regenerated (canopy cover of $<7 \%$ ), production was $>3$ times higher $(1110$ and 1380 fruits $\mathrm{m}^{-2}$ ). These data suggest that fruit production in this 25-year-old burn already was declining in sites where trees had restocked successfully. This trend was corroborated in the second field season by establishing 5 plots in the Vermilion burn at sites where the forest canopy varied from 2 to $75 \%$. The data showed a negative correlation between fruit production and forest canopy cover (Spearman's $r_{s}=-1.0, P=0.02$ ).

\section{$>50$ Years After Fire}

In older-aged burns, fruit production varied from 4 to 1770 fruits $\mathrm{m}^{-2}$, primarily according to forest canopy cover (Fig. 4). Thus, fruit production depends in large part on the rate of forest regeneration following fire, which in turn depends on site and fire characteristics. Fig. 4 generalizes the possible outcomes of postfire buffaloberry fruit production, depending on the rate of forest regeneration. As already noted, plots in the Vermilion burn, 25 and 26 years postfire, already demonstrated reduced fruit production associated with lodgepole pine regeneration.

\section{Discussion}

The negative association between buffaloberry fruit production and forest canopy cover is consistent with the negative relationship observed generally between tree-crown cover and understory production (e.g., Moir 1966, Alaback 1982). Investigators also have shown a relationship between forest canopy (or light intensity) and reproductive output in understory plants (Pitelka et al. 1980).
Wildfire often determines forest cover and hence may affect understory fruit production (Martin 1983, Ross and La Roi 1990). The forest overstory may reduce understory photosynthesis and thus the energy that shrubs can allocate to seed and fruit production. Species may vary in allocation, however. Some species apparently invest in sexual reproduction only when extra resources are available, whereas others may vary vegetative growth but maintain relatively constant sexual reproductive effort (Pitelka et al. 1980). Although trees reduce light intensity in the understory, the influence of trees on soil conditions also may reduce understory production (Moir 1966, Riegel et al. 1992). This topic was not addressed in my study.

Because of the negative association between forest overstory and fruit production, the rate of overstory regeneration following disturbance is important in determining the longevity of productive, early-successional sites (Zager et al. 1983). In my study area, spruce was very slowly restocking certain NE slopes in a 1936 burn (open C37 vegetation) possibly because of cool site conditions on northerly slopes. Fire severity also may have been a contributing factor in that 1936 was an exceptionally dry year in North America, with many large, high intensity fires (Heinselman 1973, White 1985). Repeated or severe fires can remove conifer seed sources and thus lead to persistent shrubland (Wright and Bailey 1982:282). Some south-facing slopes in my study area also were restocking slowly to conifers. Xeric, south-facing slopes typically have more frequent and severe fires, unfavorable conditions for conifer seedling establishment, and high grazing and browsing pressure from wintering ungulates that can even produce a zootic grassland/shrubland climax (Wright and Bailey 1982:262, Stahelin 1943). Frequently disturbed or flooded riverbottom alluvium with high coarse-fragment content also may be slow to develop forest cover. This potential buffaloberry habitat type, characteristic of gravel floodplains, outwashes, and braided 


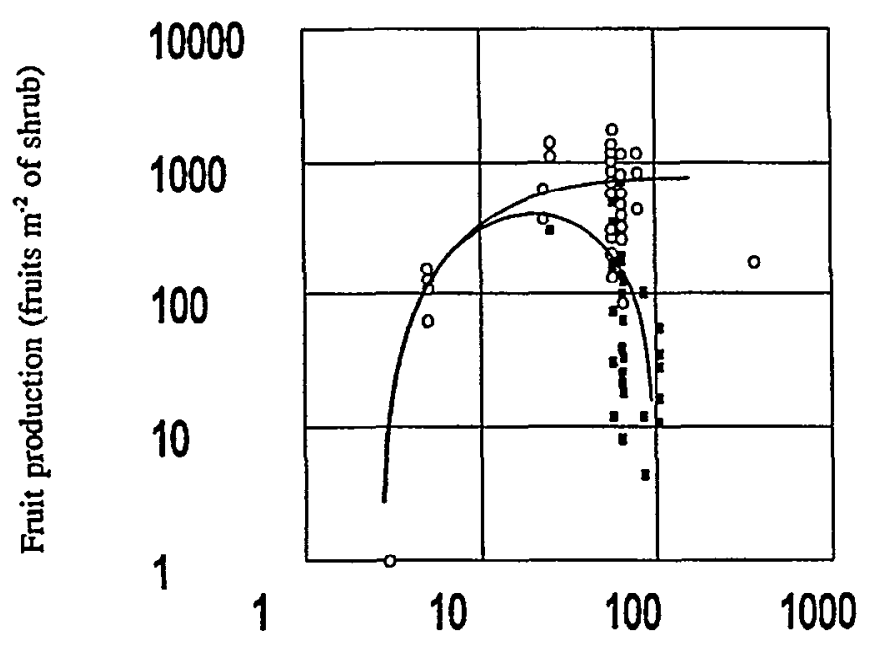

Years since fire

Fig. 4. Buffaloberry fruit production plotted against years since fire, Banff National Park, Alberta. Both variables are plotted on a logarithmic scale (1993 data). Curves generalize 2 possible outcomes of postfire succession: lower fruit production with, and higher fruit production without, normal forest regeneration following fire such as would occur on mesic sites at moderate elevation with nonnortherly aspect. Curves fitted by eye. $\mathrm{O}=$ low forest canopy cover (densiometer reading $<50 \%$ ). $\mathbf{E}=$ high forest canopy cover (densiometer reading $\leq 50 \%$ ).

streams (e.g., Pearson 1975:9, 30, Murie 1981:13) was rare in my study area.

Given my small sample size and emphasis in the Cascade on known bear feeding sites, the extent of geographic variation in buffaloberry fruit production within Banff National Park remains largely unaddressed. Approximately two-thirds of my Cascade sample plots were in known feeding sites. Under the assumption that bears are optimal foragers (Hamer 1985), some or all of these sites may have had greater fruit production than would characterize randomly-selected buffaloberry habitat-1 possible explanation for the higher fruit production recorded in the Cascade versus Spray study areas. Alternatively, the difference between the Cascade and the Spray (if real and not simply the result of sampling bias) could reflect geographic variation due to environmen-

Table 6. Buffaloberry fruit production and shrub height 23 and 25 years following fire in Banff National Park, Alberta. Data for both plots are given for the Ghost burn; other values are mean \pm standard deviation. Buffaloberry shrub height for plots in older burns is provided for comparison (1993 data).

\begin{tabular}{lccccc}
\hline Fire & Year & $\begin{array}{c}\text { Years } \\
\text { since fire }\end{array}$ & Fruit production & Shrub height & $\begin{array}{r}\text { Number } \\
\text { of plots }\end{array}$ \\
\hline \multirow{3}{*}{ Ghost } & 1970 & 23 & 380 and 630 & 33 and 50 & 2 \\
Vermilion & 1968 & 25 & $930 \pm 560$ & $106 \pm 13$ & 3 \\
- & - & $\geq 57$ & (fruits $^{-2}$ & $89 \pm 19$ & 41 \\
\hline
\end{tabular}

${ }^{3}$ Fruit production varies with forest canopy cover, see Figure 4 for data. tal or genetic differences. However, it is significant that the strong negative relationship between fruit production and forest canopy cover held for the 3 study areas examined in this regard (Cascade, Spray, and Vermilion).

My sampling also was limited in time; 2 years of data constrain generalization, especially considering the large annual variation that characterizes fruit crops. Although one might hypothesize that the same relative relationships would hold during years of higher or lower crops, this is not necessarily so. Similarly, different weather patterns could modify relationships between fruit production and environmental parameters.

I have assumed that as long as buffaloberry shrubs are reasonably dense (e.g., $>5 \%$ cover), bears will select feeding sites based on fruit density on buffaloberry shrubs. This assumption is supported by (1) observations that grizzly bears feed on shrubs bearing numerous fruits, with shrub cover itself varying from dense ( $>75 \%$ cover) to scattered ( $<5 \%$ cover) in important feeding sites (Hamer and Herrero 1987a); and (2) foraging models: bite size is an important regulator of herbivore intake rate, whereas food production per area (e.g., fruits ha ${ }^{-1}$ or $\mathrm{kg}_{\text {fruits }} \mathrm{ha}^{-1}$ ) may not be significant (compare Gross et al. 1993). I assume that when bears feed on buffaloberry, bite size (i.e., the number of fruits bite ${ }^{-1}$ ) is highly associated with fruit production per area of shrub. My sampling design and study implications rest on these assumptions. If, however, bears select for overall food availability (fruits $\mathrm{ha}^{-1}$ ), then habitat quality would be strongly influenced by the product of fruit production per area of shrub and the cover of buffaloberry shubs (Noyce and Coy 1990:17). The inclusion of shrub cover in the equation to determine fruit availability would lead to different relationships between fruit production per area of habitat and environmental variables than those identified in this study for fruit production per area of shrub.

\section{Management Implications}

Wildfires were instrumental in creating the early successional communities where I recorded high buffaloberry fruit production. Although not the case for all soft-fruit producing shrubs (Kardell 1980, Noyce and Coy 1990), buffaloberry evidently produces more fruit where trees are few or absent. Prescription burns that are stand-replacing crown fires can lead to productive buffaloberry feeding habitat for bears following $a \geq 5$ year lag required for shrubs to regenerate postfire. In the Minnewanka prescribed burn unit, moderate fruit production occurred 5 years after fire.

Since it can be hazardous to attempt a high-intensity controlled burn, 2 (or perhaps more) prescribed fires may be required to achieve the desired reduction in tree-crown cover. Multiple burns may duplicate more closely the effects of a natural fire on fuel loads, although ecologically the effects may differ because conifers regenerating after the first fire may be burned before they have developed viable seed (I. Pengelly, Parks Canada, personal communication). A "double prescribed burn" strategy has been applied in Banff National Park to the Palliser and Minnewanka burn units (Parks Canada, unpublished data).

Buffaloberry occurs across a wide range of habitat, from riparian zones to the most xerophytic forest communities of the Canadian Rocky Mountains. My most productive plot was a NEfacing, willow-dominated slope slowly succeeding directly to spruce. More generally, fruit production in my 1993 plots tended to increase from SSW to NNE slopes. Limited data collected in the Cascade Valley also suggested that NE aspects were more 
productive than SW slopes in 1978 (Hamer 1985:132). Prescribed fire, on the other hand, most likely will be applied to southerly aspects. When north-facing slopes are sufficiently dry to carry fire, then the fire hazard on adjacent southerly slopes likely would be unacceptably high. Prescribed fires in Banff National Park to date have been applied to slopes with southerly aspect, and buffaloberry has successfully regenerated and produced fruit on these sites (i.e., the Palliser and Minnewanka burns, respectively). However, restricting prescribed fire to southerly slopes reduces the portion of the landscape subject to stand-replacing fire, and also excludes the possibly more productive, northerly aspects.

In a large park such as Banff $\left(6,600 \mathrm{~km}^{2}\right)$, where forested valleys often are isolated by effective barriers of alpine tundra, rock, and snowfields, some large wilderness tracts could be safely burned by planned or natural-ignition prescribed fires. Under dry conditions, a stand-replacing fire could run through valley bottom and NE aspect forests in addition to the more easily burned southerly slopes. This would produce extensive successional communities productive not only in buffaloberry fruit but also in hedysarum (Hedysarum spp. L.) roots, bearberry, ants, elk (Cervus elaphus), and other foods important to grizzly bears (Hamer and Herrero 1987b). Alternatively, catastrophic crown fires in the subalpine forest, recurring on a several-hundred year cycle and coincident with fuel build-up and critical weather conditions (Romme 1982, Johnson 1992), such as occurred in Yellowstone National Park in 1988 (Blanchard and Knight 1990), may eventually create and perhaps maintain highly productive bear feeding habitat in Banff National Park.

\section{Literature Cited}

Achuff, P.L. 1982. Key to vegetation types, p. 142-145. In: W.D. Holland and G.M. Coen (eds.), Ecological (biophysical) land classification of Banff and Jasper National Parks. Volume II: soil and vegetation resources. Alberta Inst. of Pedology Pub. SS-82-44.

Alaback, P.B. 1982. Dynamics of understory biomass in Sitka sprucewestern hemlock forests of southeast Alaska. Ecol. 63:1932-1948.

Blanchard, B.M. and R.R. Knight. 1990. Reactions of grizzly bears, Ursus arctos horribilis, to wildfire in Yellowstone National Park, Wyoming. Can. Field-Natur. 104:592-594.

Cole, G.F. 1963. Range survey guide. USDI Nat. Park Serv. and Grand Teton Nat. Hist. Assoc. Grand Teton Nat. Park, Moose, Wyo.

Corns, I.G.W. and P.L. Achuff. 1982a. Vegetation type descriptions, p. 75-142. In: W.D. Holland and G.M. Coen (eds.), Ecological (biophysical) land classification of Banff and Jasper National Parks. Alberta Inst. of Pedology Pub. SS-82-44.

Corns, I.G.W. and P.L. Achuff. 1982b. Succession and climax, p. 146-148. In: W.D. Holland and G.M. Coen (eds.), Ecological (biophysical) land classification of Banff and Jasper National Parks. Alberta Inst. of Pedology Pub. SS-82-44.

Dixon, W.J. ed. 1992. BMDP statistical software. Univ. of Calif. Press, Berkeley, Calif.

Gross, J.E., N.T. Hobbs, and B.A. Wunder. 1993. Independent variables for predicting intake rate of mammalian herbivores: biomass density, plant density, or bite size? Oikos 68:75-81.

Hamer J.D.W. 1985. Feeding ecology of grizzly bears in the Cascade and Panther valleys of Banff National Park, Alberta. Ph.D. Thesis, Univ. Calgary. Calgary, Alberta.

Hamer, D. and S. Herrero. 1987a. Grizzly bear food and habitat in the Front Ranges of Banff National Park, Alberta. Int. Conf. Bear Res. and Manage. 7:199-213.
Hamer, D. and S. Herrero. 1987b. Wildfire's influence on grizzly bear feeding ecology in Banff National Park, Alberta. Int. Conf. Bear Res. and Manage. 7:179-186.

Heinselman, M.L. 1973. Fire in the virgin forests of the boundary waters canoe area, Minnesota. Quaternary Res. 3:329-382.

Herrero, S. 1985. Bear attacks: their causes and avoidance. Winchester Press, Piscataway, N.J.

Holcroft, A.C., and S. Herrero. 1991. Black bear, Ursus americanus, food habits in southwestern Alberta. Can. Field-Natur. 105:335-345.

Janz, B. and D. Storr. 1977. The climate of the contiguous mountain parks: Banff, Jasper, Yoho, Kootenay. Dep. Environ., Atmospheric Environ. Serv. Project Rep. No. 30.

Johnson, E.A. 1992. Fire and vegetation dynamics: studies from the North American boreal forest. Cambridge Univ. Press, Cambridge.

Kardell, L. 1980. Occurrence and production of bilberry, lingonberry and raspberry in Sweden's forests. Forest Ecol. and Manage. 2:285-298.

Kendall, K.C. 1986. Grizzly and black bear feeding ecology in Glacier National Park, Montana. USDI Nat. Park Serv., progress report. West Glacier, Mont.

La Roi, G.H. and R.J. Hnatiuk. 1980. The Pinus contorta forests of Banff and Jasper National Parks: a study in comparative synecology and syntaxonomy. Ecol. Monogr. 50:1-29.

Lemmon, P.E. 1956. A spherical densiometer for estimating forest overstory density. Forest Sci. 2:314-320.

Lindzey, F.G., K.R. Barber, R.D. Peters, and E.C. Meslow. 1986. Responses of a black bear population to a changing environment. Int. Conf. Bear Res. and Manage. 6:57-63.

McLean, A. 1969. Fire resistance of forest species as influenced by root systems. J. Range Manage. 22:120-122.

Martin, P. 1983. Factors influencing globe huckleberry fruit production in northwestern Montana. Int. Conf. Bear Res. and Manage. 5:159-165.

Mattson, D.J., B.M. Blanchard, and R.R. Knight. 1991. Food habits of Yellowstone grizzly bears, 1977-1987. Can. J. Zool. 69:1619-1629.

Mattson, D.J., B.M. Blanchard, and R.R. Knight. 1992. Yellowstone grizzly bear mortality, human habituation, and whitebark pine seed crops. J. Wildl. Manage. 56:432-442.

Moir, W.H. 1966. Influence of ponderosa pine on herbaceous vegetation. Ecol. 47:1045-1048.

Mueggler, W.F. 1965. Ecology of seral shrub communities in the cedarhemlock zone of northern Idaho. Ecol. Monogr. 35:165-185.

Murie, A. 1981. The grizzlies of Mount McKinley. USDI Nat. Park Serv. Scientific Monogr. Ser. No. 14. Washington, D.C.

Nakamura, T. 1986. BMDP program for piecewise linear regression. Computer Methods and Programs in Biomedicine 23:53-55.

Noste, N.V. and C.L. Bushey. 1987. Fire response of shrubs of dry forest habitat types in Montana and Idaho. USDA For. Serv. Gen. Tech. Rep. INT-239. Intermountain Res. Sta., Ogden, Ut.

Noyce K.V. and P.L. Coy. 1990. Abundance and productivity of bear food species in different forest types of northcentral Minnesota. Int. Conf. Bear Res. and Manage. 8:169-181.

Parker, A.J. 1982. The topographic relative moisture index: an approach to soil-moisture assessment in mountain terrain. Physical Geogr. 3:160-168.

Pearson, A.M. 1975. The northern interior grizzly bear Ursus arctos L. Can. Wildl. Serv. Rep. Ser. No. 34.

Pitelka, L.F., D.S. Stanton, and M.O. Peckenham. 1980. Effects of light and density on resource allocation in a forest herb, Aster acuminatus (Compositae). Amer. J. Bot. 67:942-948.

Raine, R.M. and J.L. Kansas. 1990. Black bear seasonal food habits and distribution by elevation in Banff National Park, Alberta. Int. Conf. Bear Res. and Manage. 8:297-304.

Reid, D.G., A.H. Taylor, Hu Jinchu, and Qin Zisheng. 1991. Environmental influences on bamboo Bashania fangiana growth and implications for giant panda conservation. J. Appl. Ecol. 28:855-868.

Riegel, G.M., R.F. Miller, and W.C. Krueger. 1992. Competition for resources between understory vegetation and overstory Pinus ponderosa in northeastern Oregon. Ecol. Appl. 2:71-85. 
Rogers, L. 1976. Effects of mast and berry crop failures on survival, growth, and reproductive success of black bears. Trans. North Amer. Wild. and Natur. Resour. Conf. 41:431-438.

Romme, W.H. 1982. Fire and landscape diversity in subalpine forests of Yellowstone National Park. Ecol. Monogr. 52:199-221.

Ross, M.S. and G.H. La Roi. 1990. Above-ground biomass allocation by four understory vascular plant species in central Alberta jack pine, Pinus banksiana, forests. Can. Field-Natur. 104:394-402.

Russell, R.H., J.W. Nolan, N.G. Woody, and G.H. Anderson. 1979. A study of the grizzly bear (Ursus arctos L.) in Jasper National Park, 1975-1978. Final Rep. Can. Wildl. Serv., Edmonton, Alberta.

Stahelin, R. 1943. Factors influencing the natural restocking of high altitude burns by coniferous trees in the central Rocky Mountains. Ecol. 24:19-30.

Stickney, P.F. 1980. Data base for post-fire succession, first 6 to 9 years, in Montana larch-fir forests. USDA For. Serv. Gen. Tech. Rep. INT62. Intermountain Forest and Range Exp. Sta., Ogden, Ut.
White, C. 1985. Wildland fires in Banff National Park, 1880-1980. Environ. Can., Nat. Parks Branch, Occasional Paper No. 3. Supply and Services Can. Ottawa.

Wielgus, R.B. 1986. Habitat ecology of the grizzly bear in the southern Rocky Mountains of Canada. M.S. Thesis, Univ. Idaho, Moscow, Ida.

Wright, H.A. and A.W. Bailey. 1982. Fire ecology, United States and southern Canada. John Wiley and Sons, New York, N.Y.

Young, J.A. and C.G. Young. 1992. Seeds of woody plants in North America, revised edition. Dioscorides Press, Portland, Ore.

Zager, P., C. Jonkel, and J. Habeck. 1983. Logging and wildfire influence on grizzly bear habitat in northwestern Montana. Int. Conf. Bear Biol. and Manage. 5:124-132.

Zar, J.H. 1984. Biostatistical analysis, second edition. Prentice-Hall, Englewood Cliffs, N.J.

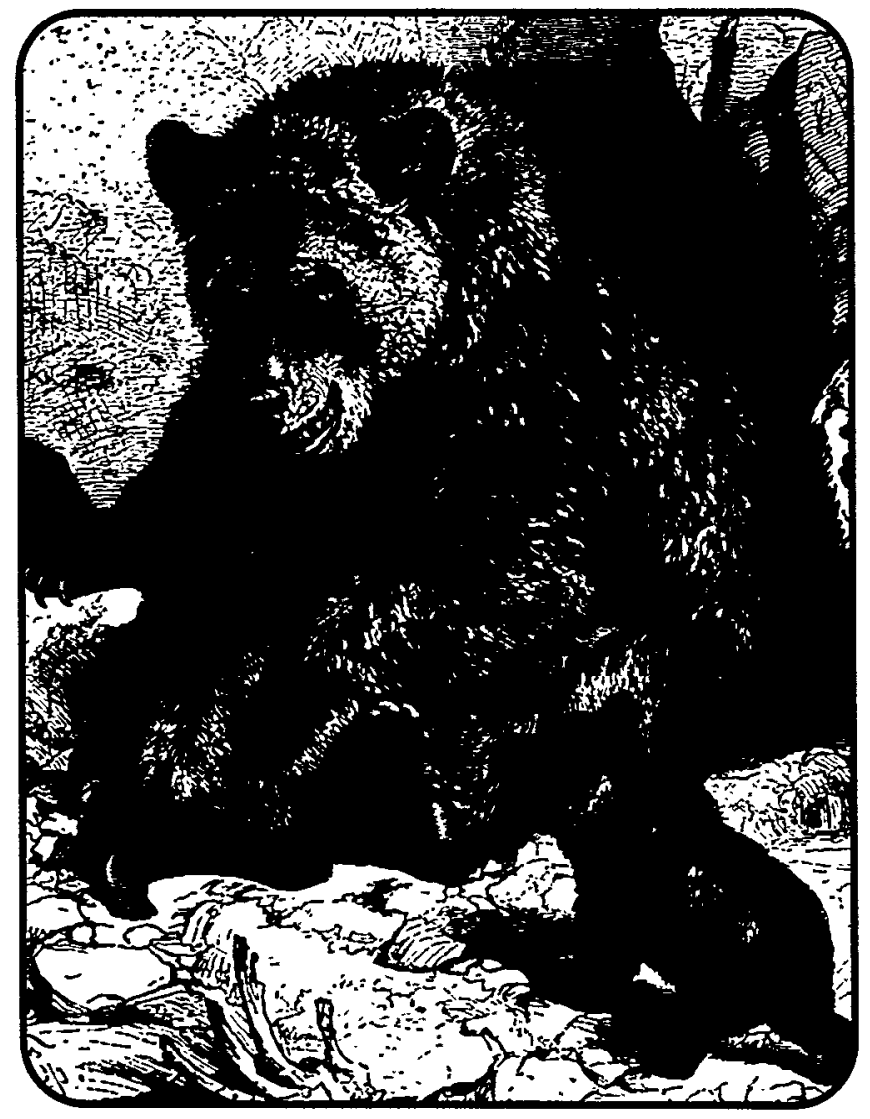

